\title{
Analysis of biochemical and nutritional constituents of different size groups of Macrobrachium malcolmsonii (Milne- Edwards, 1844) (Decapoda: Palaemonidae) for the identification of its nutritional requirements
}

\section{Thirumurugan Ramasamy*, Arun Sridhar, Rajkumar Krishnasamy Sekar and Sathya Deepika Murugesan}

Laboratory of Aquabiotics/Nanoscience. Department of Animal Science. Centre of Excellence in Life Sciences. Bharathidasan University. Tiruchirappalli-620 024. Tamil Nadu. India.*Email: ramthiru72@bdu.ac.in.

\begin{abstract}
Prawns have been contributing almost $15 \%$ by value in global aquaculture production. In this study, different size groups $(4-19 \mathrm{~cm})$ of fresh water prawn, Macrobrachium malcolmsonii (Milne-Edwards, 1844) (Decapoda: Palaemonidae) were collected from the Cauvery River, Tamil Nadu, India, and estimated to identify the protein (P), lipid (L) and carbohydrate (CHO) level. The adult prawns exhibited highest values $61.63 \% \mathrm{P}, 6.95 \% \mathrm{~L}$ and $5.40 \%$ CHO. The gas chromatography of small size groups of prawns showed increased amount in various fatty acids such as palmitic acid, stearic acid etc. The tissues result determined by high performance liquid chromatography showed that the amino acids such as Aspartic acid, Lysine etc., are high in adult groups. The protein profile of the muscle samples displayed various polypeptides ranging from 200 to $20 \mathrm{kDa}$. Results of this study clearly implied the biochemical and nutritional constituents of freshwater prawn, $M$. malcolmsonii. It would be useful to design the required composition of feed in order to get higher yield at lower cost production.
\end{abstract}

Keywords: Macrobrachium malcolmsonii; SDS-PAGE; HPLC; Fatty acid profile; Gas chromatography.
Received

October 14, 2017

Accepted

December 12, 2017

Released

December 31, 2017

Open Access

Full Text Article

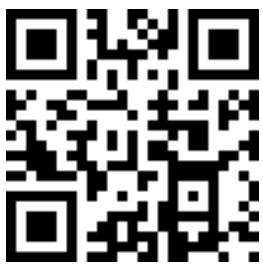

\footnotetext{
ORCIID

(C) 0000-0002-8902-5284

Thirumurugan

Ramasamy

(D) 0000-0003-4571-8596

Arun Sridhar

(D) 0000-0003-4155-4563

Rajkumar Krishnasamy Sekar

(D) 0000-0002-5211-4961

Sathya Deepika

Murugesan
} 


\section{Introduction}

Aquaculture is the unique and
proven technology to produce
proteinaceous animal food for the teeming
world population. Prawn constitutes an
important aquatic resource for human
consumption and its commercial exploitation is on the increase. The FAO (2012) report indicated that the contribution of freshwater aquaculture production has gradually increased up to $65.6 \%$ in 2010 from around $60 \%$ in the 1990s. Asian aquaculture is predominated by crustaceans $(9.7 \%)$ and others as well. The contribution of China to the world aquaculture production volume in 2010 was $61.4 \%$. Other major producers in Asia (India, Viet Nam, Indonesia, Bangladesh, Thailand, Myanmar, the Philippines, and Japan) are among the world's top producers. In India, fish culture has gained phenomenal significance in recent years. The culture of Penaeid prawns in coastal farms has received considerable attention in many countries due to their high demand and price in markets world over. The freshwater prawns of the genus Macrobrachium are the most suitable species for aquaculture in many parts of the world. The Macrobrachium species are distributed throughout the tropical and subtropical zones (Laxmappa and Savalla, 2015). The common species of freshwater prawns available in India are the giant freshwater prawn Macrobrachium rosenbergii, M. malcolmsonii, M. idae, M. nobilii, M. rudae, M. lamarrei lamarrei. Among these species, $M$. rosenbergii and M. malcolmsonii are the larger sized fast growing species, widely considered for soft meat production. Both $M$. rosenbergii and M. malcolmsonii command the same price in export market (New, 2002). Their good characteristics such as the fast growth rate, high tolerance to a wide range of hydrological parameters and less cannibalistic tendency makes them the appropriate species for aquaculture. M. malcolmsonii is widely distributed throughout India, especially in the rivers draining into the Bay of Bengal. This species grows fast and has good taste (Kanaujia et al., 1997).

Various endogenous and exogenous factors play a dynamic role in the composition of crustaceans. To better understand nutritional requirements of M. malcolmsonii, the biochemical composition of their body tissues at different growing stages and its variation in relation to the environment will be very useful. The protein, lipid, and carbohydrate levels of prawn tissue would indicate the basic energy-giving nutrient profiles. The ash content of the body suggests the mineral needs of prawns. Furthermore, a probe into the amino acid and fatty acid profiles will lead us to understand the more specific and balanced nourishment to optimize the requirement of the prawns and improve their healthy growth.

The purpose of this study was to obtain information on protein, amino acids, and fatty acids composition of muscle tissues in fresh water prawn M. malcolmsonii during different growth stages, which may be helpful in better understanding the dietary requirements of M. malcolmsonii.

\section{Materials and methods}

The different size of M. malcolmsonii were collected from the River Cauvery at lower Anicut (latitude $11^{\circ} 15^{\prime} \mathrm{N}$; longitude $79^{\circ} 30^{\prime}$ E) near Kumbakonam, Tamil Nadu, India. The prawns were brought in oxygenated polyethylene bags to the laboratory and maintained in $50 \mathrm{~L}$, well-aerated plastic tanks. The prawns were separated based on its size, group of juveniles (up to $5 \mathrm{~cm}$ ), sub adult groups $(5-12 \mathrm{~cm}$ ) and adult groups (above $12 \mathrm{~cm}$ ). The different size groups of prawns used in this study are presented in Table 1.

The prawns $(n=10)$ from each stage of I to VI, were sacrificed and the muscles were segregated. Collected tissues were pooled, weighed separately and used for the analysis of individual parameters protein $(\mathrm{P})$, lipid $(\mathrm{L})$, carbohydrate $(\mathrm{CHO})$, fatty acid (FA), and amino acid (AA). 
Table 1. Different size groups of prawns used for biochemical studies.

\begin{tabular}{cccc}
\hline Size groups & Length groups $(\mathrm{cm})$ & Mean length $(\mathrm{cm})$ & Mean weight $(\mathrm{g})$ \\
\hline I & $4.0-4.9$ & $4.26 \pm 0.251$ & $0.7229 \pm 0.041$ \\
II & $5.0-7.0$ & $5.83 \pm 0.305$ & $1.7006 \pm 0.250$ \\
III & $7.1-11.0$ & $7.43 \pm 0.404$ & $3.6342 \pm 0.433$ \\
IV & $11.1-12.0$ & $11.33 \pm 0.251$ & $14.7179 \pm 0.677$ \\
V & $12.1-14.0$ & $12.43 \pm 0.404$ & $21.9579 \pm 2.652$ \\
VI & $17.0-19.0$ & $17.76 \pm 0.642$ & $68.8674 \pm 7.865$ \\
\hline
\end{tabular}

\section{Protein estimation}

Total protein content in the muscle tissue was estimated by Lowry et al. (1951). Samples were ground with $10 \%$ TCA. Homogenate was centrifuged at 3,000 rpm for $15 \mathrm{~min}$. The precipitate was taken in a test tube and reagents were added and left incubation for $20 \mathrm{~min}$ in dark. The developed blue color was measured at 720 $\mathrm{nm}$ in UV-Visible Spectrophotometer. Bovine serum albumin (BSA) was used as standard. The protein concentration was expressed in $\mathrm{mg} / \mathrm{g}$ of muscle tissue.

\section{Lipid estimation}

The concentration of total lipids from the prawn tissues was evaluated by gravimetric method (Folch et al., 1957). The tissues were extracted using chloroform and methanol (2:1). The extract was filtered and the extraction procedure was repeated to ensure maximum removal of lipids and vortexed thoroughly to remove water soluble impurities. The moisture present in the lipid was removed by addition of anhydrous sodium sulphate crystals. The filtrate was dried by keeping it in an oven at $60{ }^{\circ} \mathrm{C}$. The final weight and initial weight were taken for calculation to estimate the lipid. The values were expressed as $\mathrm{mg} / \mathrm{g}$ of the sample.

\section{Carbohydrate estimation}

Total carbohydrate content of the muscle was measured by Anthrone method (Dubois et al., 1956). The tissues were homogenized with TCA and centrifuged at $4000 \mathrm{rpm}$ for $15 \mathrm{~min}$. Anthrone reagent was added and placed in boiling water bath for $10 \mathrm{~min}$. Then it was cooled in dark at room temperature for $30 \mathrm{~min}$. The optical density (OD) was measured at $620 \mathrm{~nm}$ in UV-
Visible Spectrophotometer. The amount of carbohydrate present in the sample was found out using glucose as standard.

\section{Electrophoretic analysis of protein}

The muscle tissue was homogenized with refrigerated phosphate buffer ( $50 \mathrm{mM}$; pH 7.2) in the ratio of 1:5. The homogenate was then centrifuged at $11,200 \mathrm{~g} / \mathrm{min}$ for $20 \mathrm{~min}$ at $5{ }^{\circ} \mathrm{C}$. The supernatant was separated and stored at -80 ${ }^{\circ} \mathrm{C}$ until analysis. Equal amount of protein $(120 \mu \mathrm{g})$ was loaded for separation. Muscle samples were subjected to linear SDSPAGE using 6\% stacking gel and 10\% separating gel (Laemmli, 1970). The gels were stained with $0.2 \%$ coomassie brilliant blue R-250 in 50\% methanol and 7\% acetic acid for $6 \mathrm{~h}$. The gel was then de-stained with 30\% methanol and $7 \%$ acetic acid solution until the background was clear.

\section{Amino acid analysis}

The tissue samples were analyzed for amino acid composition using High Performance Liquid Chromatography (HPLC). The filtered derivative amino acid sample was injected into the $\mathrm{C}-18$ reverse phase column at the temperature of $40{ }^{\circ} \mathrm{C}$ and analyzed using sodium acetate buffer and acetonitrile as solvent. The samples were compared with a chromatogram of standard amino acids.

\section{Fatty acid profile}

Lipids were extracted from prawns and fatty acids were saponified and methylated. From each vial, the fatty acid methyl ester (FAME) was injected into the Gas Chromatography (GC) column (Miller and Berger, 1985) fused with DEGS 
(Diethylene Glycol Succinate) column equipped with FID (Flame Ionization Detector). The sample was injected at 200 ${ }^{\circ} \mathrm{C}$ with nitrogen as the carrier gas. The column was operated isothermally at oven temperature of $180{ }^{\circ} \mathrm{C}$ and a detector temperature of $210^{\circ} \mathrm{C}$. The individual fatty acids were identified and quantified by using the FAME standard under similar conditions. The results were expressed in $\mathrm{mg} / \mathrm{g}$ of lipid sample.

\section{Results}

The biochemical compositions of body muscles in different size groups of $M$. malcolmsonii are presented in Figure 1. The higher amount of protein was found in the size group of VI (61.63\%) and very lower amount was observed in the size group of $\mathrm{V}$ (50.83\%). Lipid content showed wide fluctuations among the size groups. The higher amount of lipid was present in the size group of VI (6.95\%) and lower amount was noticed in the size group of II (4.93\%). The highest amount of ash content was present in the size group VI (17.28\%) and lowest amount in size group I (8.05\%). The ash content gradually increased from group I to group VI (juveniles to adult prawns). The moisture content also showed increasing values from group I to group VI. The higher amount of moisture in group VI (83.57\%) and lower amount in group I (70.21\%) were recorded. Carbohydrate was maximum in the size group $\mathrm{V}(5.40)$ and minimum in the size group I (2.85\%).

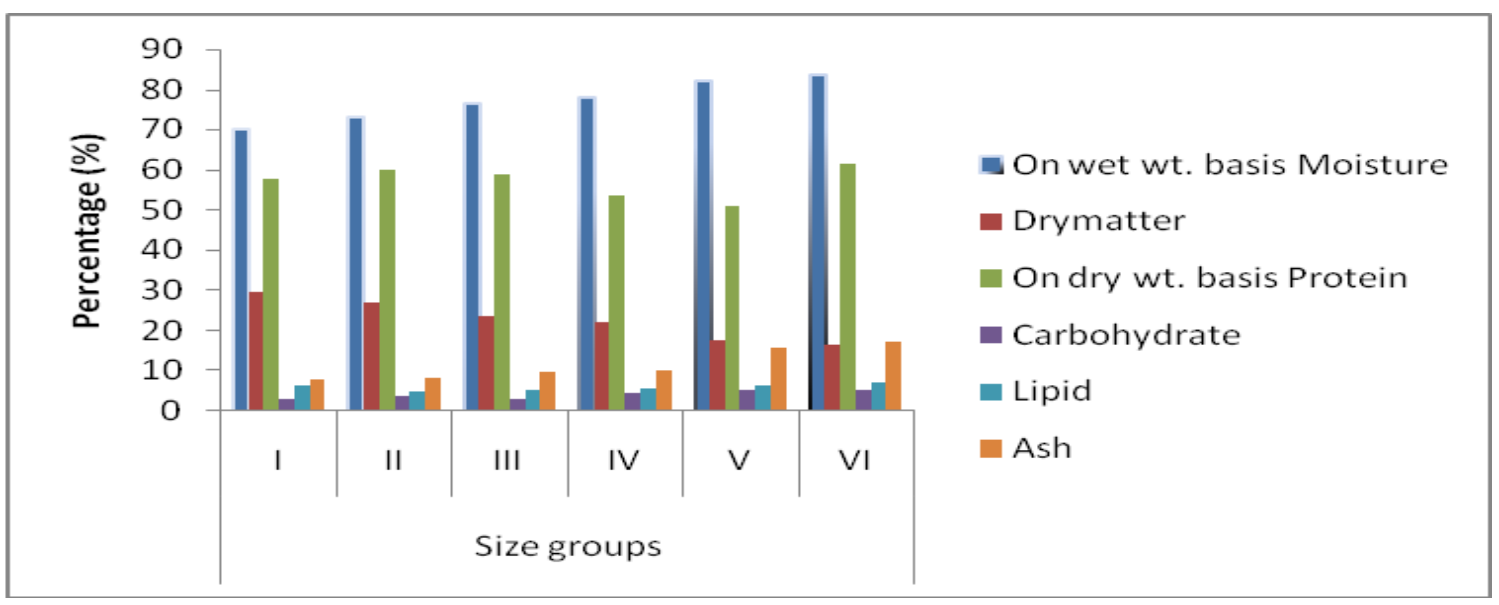

Figure 1. Biochemical constituents of muscle tissues in different size groups of Macrobrachium malcolmsonii

The SDS-PAGE (10\%) for muscle showed several polypeptides between 200 and $20 \mathrm{kDa}$ (Figure 2). The maximum numbers of 16 bands were found in size groups of II-VI and minimum number of 12 bands were recorded in size group of I. In group I, the 170, 140, 80, 30 and $25 \mathrm{kDa}$ proteins were found to be thick and therefore deeply stained. In other groups, the staining intensity of $170,140,30,25$ and $20 \mathrm{kDa}$ polypeptides were found to be thinner when compared to group I. However, the band size of $80 \mathrm{kDa}$ protein in group II-VI was found to be more in comparison to that of group I. The 200 and $90 \mathrm{kDa}$ proteins were found to be absent in group I, when noted with the other groups. The $70 \mathrm{kDa}$ protein was found to be presented in group I and group II only. 


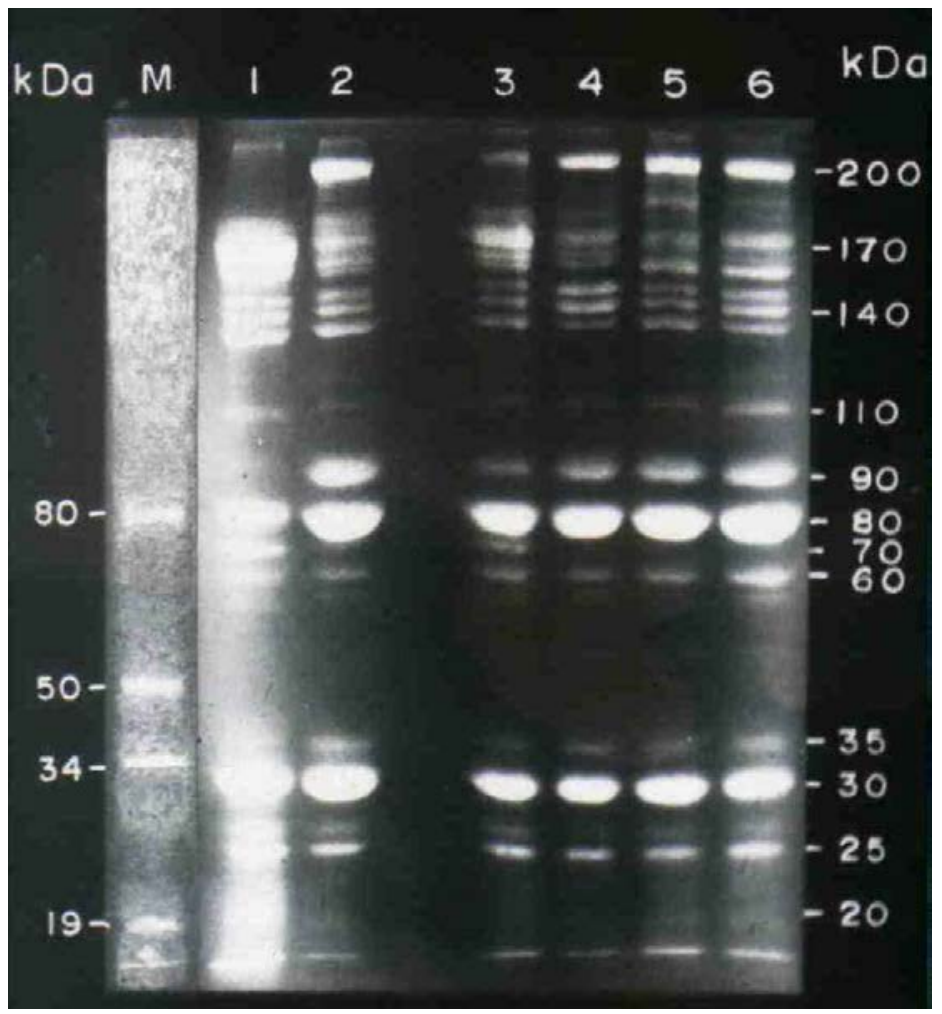

Figure 2. Protein profile of the muscles of Macrobrachium malcolmsonii (M-Marker; 1 to 6-Different size groups).

The amino acid compositions of the muscles are presented in Table 2. The essential amino acids arginine, lysine, and threonine are presented in higher amounts in all size groups. The higher amount of lysine noted in the group VI (26.09\%) and the lowest amount in the group V (11.18\%). The maximum amount of arginine noted in the size group VI (20.40\%) and minimum amount in the size group IV (10.19\%) and lowest amount in VI group of prawns (5.82\%). Leucine ranged from $0.61 \%$ to $4.93 \%$ in group VI to group I. The high amount of phenylalanine is present in the II group (14.45\%) and low amount in VI group of prawns $(1.00 \%)$. Histidine was not found in group I and it is present in the remaining groups of prawns. The aspartic acid was available in all size groups of M. malcolmsonii. The glutamic acid occurred in all size groups of prawns. The maximum amount of serine was noted in the VI group (17.53\%) and minimum amount in the $\mathrm{V}$ group of prawns (1.90\%).
Fatty acid composition of different size groups of prawns is presented in Table 3. Myristic acid, pentadecanoic acid, palmitic acid, heptadecanoic acid, stearic acid, and arachidic acid are found almost in all size groups. Cis linoleic acid was found only in the II size group of prawns (0.005 mg/g lipid). The maximum amount of lauric acid was presented in I size group of prawns $(0.0312 \mathrm{mg} / \mathrm{g}$ lipid) and the minimum amount in the II size group of prawns $(0.008 \mathrm{mg} / \mathrm{g}$ lipid). The higher amount of heptadecanoic acid was presented in the group II $(0.0688 \mathrm{mg} / \mathrm{g}$ lipid) and lower amount in the group VI (0.0204 mg/g lipid). The maximum amount of stearic was recorded in group I (0.3724 $\mathrm{mg} / \mathrm{g}$ lipid) and minimum amount in group II $(0.1185 \mathrm{mg} / \mathrm{g}$ lipid). The highest amount of nondecanoic acid was noticed in group III $(0.1028 \mathrm{mg} / \mathrm{g}$ lipid) and lowest amount in group II (0.346 mg/g lipid). 
Table 2. Amino acid composition of different size groups of prawn M. malcolmsonii (expressed in mole percentage).

\begin{tabular}{lcccccc}
\hline \multirow{2}{*}{ Amino acids } & \multicolumn{7}{c}{ Size groups } \\
\cline { 2 - 7 } & I & II & III & IV & V & VI \\
\hline Alanine & 10.93 & 7.47 & 6.10 & 8.48 & 6.68 & 10.23 \\
Arginine & 18.51 & 12.53 & 11.14 & 13.97 & 10.15 & 20.40 \\
Aspartic acid & 8.54 & 9.13 & 8.01 & 9.54 & 8.73 & 10.034 \\
Cy2 & 17.84 & 7.03 & 6.52 & 16.14 & 11.25 & 7.60 \\
Glutamic acid & 4.53 & 3.96 & 4.85 & 5.01 & 4.98 & 5.24 \\
Glycine & 1.24 & 2.15 & 1.88 & 2.05 & 1.68 & 3.15 \\
Histidine & $\mathrm{ND}$ & 4.82 & 4.07 & 4.80 & 3.60 & 4.33 \\
Isoleucine & 2.49 & 1.75 & 2.06 & 1.86 & 2.54 & 3.13 \\
Leucine & 4.93 & 3.18 & 1.65 & 0.77 & 1.39 & 0.61 \\
Lysine & 18.96 & 13.97 & 14.24 & 11.54 & 11.18 & 26.09 \\
Methionine & 1.37 & 11.11 & 9.17 & 5.88 & $\mathrm{ND}$ & ND \\
Norvaline & $\mathrm{ND}$ & $\mathrm{ND}$ & $\mathrm{ND}$ & $\mathrm{ND}$ & $\mathrm{ND}$ & ND \\
Phenylalanine & 2.54 & 14.45 & 14.62 & 1.98 & 12.36 & 1.00 \\
Serine & 3.83 & 3.15 & 3.46 & 2.63 & 1.90 & 17.53 \\
Threonine & 6.43 & 8.26 & 7.28 & 10.19 & 7.54 & 5.82 \\
Tryptophan & $\mathrm{ND}$ & 6.33 & 7.43 & 6.16 & 14.82 & ND \\
Tyrosine & 8.11 & 7.68 & 5.89 & 5.92 & ND & ND \\
Valine & 4.05 & 9.75 & 8.45 & 7.64 & 17.46 & 1.13 \\
\hline
\end{tabular}

Table 3. Fatty acid composition in the muscle (mg/g of lipid) of different size groups of prawn M. malcolmsonii.

\begin{tabular}{|c|c|c|c|c|c|c|c|}
\hline \multirow{2}{*}{ Fatty acids } & & \multicolumn{6}{|c|}{ Size groups } \\
\hline & & $\mathbf{I}$ & II & III & IV & $\mathbf{V}$ & VI \\
\hline \multicolumn{8}{|c|}{ Saturated fatty acids } \\
\hline Heptanoic acid & C7:0 & ND & ND & ND & ND & ND & ND \\
\hline Caprylic acid & C8:0 & ND & ND & ND & ND & ND & ND \\
\hline Nonanoic acid & C9:0 & ND & 0.0585 & ND & ND & ND & ND \\
\hline Capric acid & C10:0 & ND & ND & ND & ND & ND & ND \\
\hline Undecanoic acid & C11:0 & ND & ND & ND & ND & ND & ND \\
\hline Lauric acid & $\mathrm{C} 12: 0$ & 0.0312 & 0.0008 & 0.0157 & 0.0100 & 0.0195 & 0.0187 \\
\hline Tridecanoic acid & C13:0 & 0.0002 & ND & 0.0002 & ND & ND & ND \\
\hline Myristic acid & C14:0 & 0.0588 & 0.0661 & 0.0497 & 0.038 & 0.0417 & 0.0419 \\
\hline Pentadecanoic acid & C15:0 & 0.0121 & 0.0431 & 0.0102 & 0.0008 & 0.0008 & 0.0007 \\
\hline Palmitic acid & C16:0 & 0.3630 & 0.1644 & 0.1324 & 0.1865 & 0.2249 & 0.2537 \\
\hline Heptadecanoic acid & C17:0 & 0.0555 & 0.0688 & 0.0418 & 0.0235 & 0.0213 & 0.0204 \\
\hline Stearic acid & C18:0 & 0.3724 & 0.1185 & 0.2966 & 0.1424 & 0.1968 & 0.1978 \\
\hline Nondecanoic acid & C19:0 & 0.0902 & 0.0346 & 0.1028 & 0.0496 & 0.0599 & 0.0610 \\
\hline Arachidic acid & C20:0 & 0.0723 & 0.0194 & 0.0215 & 0.0168 & 0.0004 & 0.0004 \\
\hline Heneicosanoic acid & C21:0 & 0.0005 & ND & ND & 0.0005 & ND & ND \\
\hline Behenic acid & C22:0 & 0.2533 & 0.8664 & 0.1800 & ND & 0.1270 & 0.1300 \\
\hline Tricosanoic acid & C23:0 & ND & ND & ND & ND & ND & ND \\
\hline Lignoceric acid & $\mathrm{C} 24: 0$ & ND & 0.0275 & 0.0196 & 0.0815 & 0.1100 & 0.1109 \\
\hline \multicolumn{8}{|c|}{ Unsaturated fatty acids } \\
\hline Palmitoleic acid & C16:1 & ND & ND & ND & ND & ND & ND \\
\hline Oleic acid & C18:1 & ND & ND & ND & ND & ND & ND \\
\hline Cis Linoleic acid & C18:2 & ND & 0.0005 & ND & ND & ND & ND \\
\hline Linolenic acid & C18:3 & ND & ND & ND & ND & ND & ND \\
\hline Arachidonic acid & C20:4 & ND & 0.0414 & ND & ND & ND & ND \\
\hline Eicosapentaenoic aci & C20:5 & ND & ND & ND & ND & ND & ND \\
\hline Decosahexaenoic aci & C22:6 & ND & ND & ND & ND & ND & ND \\
\hline
\end{tabular}




\section{Discussion}

In the current study, higher amount of protein was found in the size group VI and low protein was found in the size group $\mathrm{V}$. From the group III to V the protein level is slightly decreasing. Joshi and Diwan (1996) stated that gradual depletion of muscle protein was noticed with the advancement of maturation. The number of polypeptide bands resolved in subadult (groups II to IV) and adult (groups V and VI) stages were found to be higher when compared to juvenile prawns (group I). This reflects the synthesis of different proteins during growth and maturation. In all life forms, proteins are essential to grow, repair and maintenance of cells (Kaushik and Seiliez 2010; Gamble et al., 2015). Protein syntheses are specific to species and developmental stage and in crustaceans it is a major energy demanding process (Carter and Mente, 2014).

The muscle proteins are referred to as acidic proteins because of the presence of large amounts of aspartic acid and glutamic acid (Shamasunder and Prakash, 1994). The sweetness of the prawn muscle has been attributed to free glycine (Konosu and Yamaguchi, 1982). Cathetic proteases (Pan and Yeh, 1993) and other enzymatic proteins are also constituents of muscle proteins. Nor Faadila et al. (2013) found that in tiger prawn, Penaeus esculentus the protein is the main energy source because of changes in lipid and protein during starvation. The dry matter content of $M$. malcolmsonii was noted between $16.34 \%$ and $29.79 \%$ in different size groups. The ash content gradually increased from group I to group VI.

Generally the ash content denotes the presence of mineral element in the body tissue. The observation of increasing trend of ash content from the size groups I to VI reflects the continuous accumulation of mineral elements in their body tissue. Previous studies found that the changes are noted in the proximate chemical composition, fresh mass, water content, ash content, organic constituents, lipid and protein contents and energy levels of penaeid prawn, Penaeus monodon during reproductive stages (Suneetha et al., 2009). Hill et al. (1992) and Correia et al. (2003) reported that the content of total lipid was higher in adults than in juveniles of many crustaceans. During growth and maturation there is an increase in lipid and fatty acid content (Rosa et al., 2005).

Our results are agreed with Alava and Pascual (1987) and Sarac et al. (1993) findings of the dry matter content of whole prawn. In female prawns the polyunsaturated and saturated fatty acids levels were higher than the males (Bhavan et al., 2010). Augusto and Masui (2014) identified that in the Amazon River prawn, Macrobrachium amazonicum the male prawns showed accelerated growth than the female and they suggested that the female prawns might have utilized the energy into other pathways such as reproduction. Additionally, Ekpenyong et al. (2013) showed that the mineral elements are distributed in different parts of the prawn disproportionately.

The higher amount of carbohydrate in M. malcolmsonii was observed in group VI (5.36\%) and lower amount in group I (2.25\%). One possible explanation for these finding is that the lipid can be converted rapidly when prawn is growing. This agrees with a study by Wenjuan and Xueliang (1994), who stated that linolenic acid is used rapidly for energy, or converted into higher unsaturated fatty acids and is not retained in the tissues. The fatty acids, linolenic, alpha-linolenic and arachidonic acid are present in low concentrations.

Proteins are digested or hydrolyzed and releases free amino acids, absorbed from intestinal tract and distributed to the organs. Amino acids are used either to form new proteins or replacing the existing proteins for balancing the protein level in the body (Robert, 2002). Farmanfarmaian and Lauterio (1980) reported that, after glutamic acid, and aspartic acid the third major amino acid in the tail muscle of the freshwater prawn, $M$. rosenbergii was arginine. In this work, arginine was found in higher amount in all size groups of $M$. malcolmsonii. Arginine is associated with the flat flavor of the prawns (Weng et al., 1997). It has already been reported that 
arginine is involving in growth related processes (Hird, 1986).

As different lipids vary in their fatty acid composition, the nutritive value of prawns depends upon the quality and quantity of polyunsaturated fatty acids. In the present work, the variations in the amino acids and some fatty acids of freshwater prawn, $M$. malcolmsonii may be due to several factors such as age, moulting stage, climatic conditions, and food composition.

\section{Conclusion}

The experimental data obtained may have practical utility in understanding the body nutrient levels of $M$. malcolmsonii and also the amino acid and fatty acid profiles of the body tissues. The biochemical and nutritional data of the prawn M. malcolmsonii given above might be helpful in understanding the dietary requirements of freshwater prawn. This in turn will help in formulating the balanced diets vis-a-vis the nutritional requirements of the prawns.

\section{Acknowledgments}

The authors would like to thank Bharathidasan University for giving instrumentation facilities during the research work. The authors thank University Grants Commission Special Assistance Programme II (UGC-SAP II) and Department of Science \& Technology Fund for Improvement of S\&T Infrastructure in Higher Educational Institutions II (DST FIST II) for the support.

\section{Conflict of interest statement}

Authors declare that they have no conflict of interests.

\section{References}

Alava, V.; Pascual, F. Carbohydrate requirements of Penaeus monodon (Fabricius) Juveniles. Aquaculture, v. 61, no. 3/4, p. 211-217, 1987. https://doi.org/10.1016/00448486(87)90150-5

Augusto, A.; Masui, D. C. Sex and reproductive stage differences in the growth, metabolism, feed, fecal production, excretion and energy budget of the Amazon River prawn (Macrobrachium amazonicum). Marine and Freshwater Behavior and Physiology, v. 47, p. 373-388, 2014.

Bhavan, P. S.; Radhakrishnan, S.; Seenivasan, C.; Shanthi, R.; Poongodi, R.; Kannan, S. Proximate composition and profiles of amino acids and fatty acids in the muscle of adult males and females of commercially viable prawn species Macrobrachium rosenbergii collected from natural culture environments. International Journal of Biology, v. 2, p. 108119, 2010.

Carter, C. G.; Mente, E. Protein synthesis in crustaceans: a review focused on feeding and nutrition. Central European Journal of Biology, v. 9, no. 1, p. 1-10, 2013. https://doi.org/10.2478/s11535-013-0134-0

Correia, A.; Costa, M.; Luis, O.; Livingstone, D. Age-related changes in antioxidant enzyme activities, fatty acid composition and lipid peroxidation in whole body Gammarus locusta

(Crustacea: Amphipoda). Journal of Experimental Marine Biology and Ecology, v. 289, p. 83-101, 2003.

Dubois, M.; Gilles, K. A.; Hamilton, J. K.; Rebers, P. A.; Smith, F. Colorimetric method for determination of sugars and related substances. Analytical Chemistry, v. 28, p. 350-356, 1956.

Ekpenyong, E.; Williams, I.; Osakpa, U. Variation in the proximate, energy and mineral compositions of different body parts of Macrobrachium macrobranchion (Prawn). Journal of Food Research, v. 2, p. 150-156, 2013. https://doi.org/10.5539/jfr.v2n2p150

FAO - Food and Agriculture Organization of the United Nations. The state of world fisheries and aquaculture. Rome: FAO Fisheries and Aquaculture Department, 2012.

Farmanfarmaian, A.; Lauterio, T. Amino acid composition of the tail muscle of Macrobrachium rosenbergii-comparison to amino acid patterns of supplemented commercial feed pellets. Proceedings of the World Mariculture Society, v. 11, p. 454-462, $1980 . \quad$ https://doi.org/10.1111/j.17497345.1980.tb00140.x

Folch, J.; Less, M.; Sloane Stanley, G. H. A simple method for isolation and purification of total lipids from animal tissues. Journal of 
Biological Chemistry, v. 226, p. 497-509, 1957. Available from: <http://www.jbc.org/content/226/1/497>.

Accessed on: May 22, 2017.

Gamble, S.; Pirozzi, I.; Hall, M.; Zeng, C.; Conlan, J.; Francis, D. The effects of predigested protein sources on the performance of early-mid stage Panulirus ornatus phyllosoma. Aquaculture, v. 440, p. 17-24, 2015. https://doi.org/10.1016/j.aquaculture.2015.01.02 4

Hill, C.; Quigley, M.; Cavaletto, J.; Gordon, W. Seasonal changes in lipid content and composition in the benthic amphipods Monoporeia affinis and Pontoporeia femorata. Limnology and Oceanography, v. 37, p. 12801289, 1992. https://doi.org/10.4319/ lo.1992.37.6.1280

Hird, F. J. The importance of arginine in evolution. Comparative Biochemistry and Physiology, Part B, v. 85, p. 285-288, 1986. https://doi.org/10.1016/0305-0491(86)90001-5

Joshi, V. P.; Diwan, A. D. Biochemical changes in the tissues of female prawn Macrobrachium idella, during different breeding seasons. Journal of Aquaculture in the Tropics, v. 113, p. 227-251, 1996.

Kanaujia, D. R.; Mohanty, A. N.; Tripathi, S. D. Growth and production of Indian river prawn Macrobrachium malcolmsonii (H. Milne Edwards) under pond conditions. Aquaculture, v. 154, p. 79-85, 1997. https://doi.org/10.1016/ S0044-8486(97)00013-6

Kaushik, S.; Seiliez, I. Protein and amino acid nutrition and metabolism in fish: current knowledge and future needs. Aquaculture Research, $\quad$ v. 41, p. 322-332, 2010. https://doi.org/10.1111/j.1365-2109.2009. 02174.x

Konosu, S.; Yamaguchi, K. The flavor components in fish and shellfish. In: Martin, R. E.; Flick, G. J.; Ward, D. R. (Eds.). Chemistry and Biochemistry of Marine Food Products. Westport, CT: AVI, 1982. p. 367-404.

Laemmli, U. Changes of structural proteins during the assembly of the head of bacteriophage T4. Nature, v. 227, p. 680-685, 1970.

Laxmappa, B.; Savalla, M. K. Polyculture of the freshwater prawn Macrobrachium malcolmsonii (H. M. Edwards) in Koilsagar Reservoir of Mahabubnagar District (TS), India. International Journal of Fisheries and Aquatic Studies, v. 2, p. 147-152, 2015. Available from: <http://www.fisheriesjournal.com/archives/2015
/vol2issue4/PartC/2-4-14.pdf>. Accessed on: May 22, 2017.

Lowry, O. H.; Rosenbrough, N. J.; Fair, A. L.; Randall, R. J. Protein measurement with folin phenol reagent. Journal of Biological Chemistry, v. 193, p. 265-275, 1951. Available from: <http://www.jbc.org/content/193/1/265>. Accessed on: May 22, 2017.

Miller, L.; Berger, T. Bacteria identification by gas chromatography of whole cell fatty acids. Hewlett-Packard Application Note, p. 228241, 1985.

New, M. B. Farming freshwater prawn: a manual for the culture of the giant river prawn (Macrobrachium rosenbergii). FAO Fisheries Technical Paper, v. 428, p. 212, 2002.

Nor Faadila, M. I.; Harivaindaran, K.V.; Tajul, A. Y. Biochemical and texture property changes during molting process of tiger prawn, Penaeus monodon. International Food Research Journal, v. 20, p. 751-758, 2013. Available from: <http://www.ifrj.upm.edu.my/20 (02) 2013/34 IFRJ 20 (02) 2013 Tajul (168).pdf>. Accessed on: May 23, 2017.

Pan, B. S.; Yeh, W. T. Biochemical and morphological changes in the grass shrimp Penaeus monodon muscle following freezing by air blast and liquid nitrogen methods. Journal of Food Biochemistry, v. 17, p. 147-160, 1993. https://doi.org/10.1111/j.1745-4514.1993. tb00464.x

Rosa, R.; Costa, P. R.; Bandarra, N.; Nunes, M. L. Changes in tissue biochemical composition and energy reserves associated with sexual maturation in the ommastrephid squids Iiex coindetii and Todaropsis eblanae. Biological Bulletin, v. 208, p. 100-113, 2005.

Sarac, Z.; Thaggard, H.; Saunders, J.; Gravel, M.; Neil, A.; Cowan, R. T. Observations on the chemical composition of some commercial prawn foods and associated growth responses in Penaeus monodon. Aquaculture, v. 115, no. $1 / 2$, p. $97-110, \quad 2005$. https://doi.org/10.1016/0044-8486(93)90361-2

Shamasunder, B. A.; Prakash, V. Physiological and functional properties of proteins from prawns Metapenaeus dobsoni. Journal of Agricultural and Food Chemistry, v. 42, p. 169-174, 1994.

Suneetha, Y.; Sreenivasula Reddy, P.; Naga Jyoti, P.; Srinivasulu Reddy, M. Proximal changes during reproduction process of the penaeid prawn Penaeus monodon. World Journal of Fish and Marine Sciences, v. 1, p. 333-337, 2009. 
Weng, H. J.; Cadwallader, K. R.; Baek, H. H.; D’Abramo, L. R.; Sullivan, J. A. Manipulating the flavor of freshwater crustacea using postharvest seawater acclimation. In: Shahidi, F. C. (Ed.). Flavor and lipid chemistry of seafoods. Washington, D.C.: American Chemical Society, 1997. p. 120-130.

Wenjuan, J.; Xueliang, X. A comparative study on fatty acid composition of the prawn (Penaeus chinensis) during ovarian maturation. In: Chou, L. M.; Munto, A. D.; Lam, T. J.; Chen, T. W.; Cheong, L. K. K.; Ding, J. K.; Hooi, K. K.; Khoo, H. W.; Phang, V. P. E; Shim, K. F.; Tan, C. H. (Eds.). The Third Asian Fisheries Forum Asian Fisheries Society. Manila, The Philippines: Asian Fisheries Society, 1994. p. 701-704.

Wilson, R. P. Amino acids and Proteins. In: Halver, J. E.; Hardy, R. W. (Eds.). Fish nutrition. San Diego, Ca: Academic Press, 2002. p. $144-175$.

License information: This is an open-access article distributed under the terms of the Creative Commons Attribution License, which permits unrestricted use, distribution, and reproduction in any medium, provided the original work is properly cited. 